\title{
PRIVATE ENFORCEMENT OF CITY PLANNING
}

\section{Ailison Dunham*}

Some years ago an urban land economist observed that official city planning could effectively pre-determine the future structure of a city only if "social controls" were "applied to certain market forces or modifications ... made in the institutional framework within which the market operates. ..." While it is possible that city planning could influence market behavior merely by making information in the form of "studies" available to private sellers and buyers who do not do their own market analyses, the main influence of any city plan on the market comes from action which deters or stimulates the making of choices of an owner as to use of his land. The city plan is usually translated into action affecting the free market through zoning, official street maps, subdivision control, housing and building codes, capital budgeting, and redevelopment legislation.

Perhaps it is because the constitutional basis of most planning legislation is found in the "police power" or perhaps it is because the draftsmen of planning legislation have been influenced by experience in drafting laws regulating saloons, bawdy houses, and public nuisances, that we have looked mainly to the criminal law for the "control" applied to the operation of the free market. While by hypothesis we are trying to force property owners not to make decisions which they regard as profitable, we have expected a fine, usually a small one, to deter such owners from making these choices. ${ }^{2}$

Perhaps if planning had been in the hands of sympathetic "conveyancers" rather than the municipal or constitutional lawyer we might have had a different emphasis. We might have used the local real property tax as our model for enforcement rather than the bawdy house ordinance. While some states may impose criminal sanctions to force payment and some do impose personal responsibility for tax payment and while there is always the threat that the taxing authority will foreclose the tax "lien" if the tax is not paid, the main enforcement in practice comes from the market consequences of the existence of the tax lien. This lien is an "encumbrance" on the title. Abstractors, conveyancers, and title companies are employed by buyers in the market to ferret out the "violation" (i.e., nonpayment) of the tax. In part this is because of the strong tradition of the market that on sale title is to be

* A.B. 1936, Yankton College; LL.B. 1939, Columbia University. Professor of Law, University of Chicago.

${ }^{1}$ Ratcliff, A Land Economist Looks at City Planning, 20 J. LaNd \& P. U. Econ. 106, I07 (I944). See also Richard U. Ratcliff, Urban Land Economics 409 (1949).

${ }^{2}$ Other controls have been: power in city to abate nuisances or enjoin violations; power to cut off water and other municipal services from violator; and in redevelopment legislation the power of eminent domain and the spending power. See Joseph D. MCGoldrick, Seymour-Gradbard, and Raymond- J. Horowitz, Building Regulation in New York City (i944). 
"marketable" and in part it is because the "encumbrance" of the real property tax violation brings into the enforcement picture another potent private group tending to compel performance. Building and loan associations, banks, insurance companies, and other regulated institutional lenders who supply the bulk of the capital in the real estate market ${ }^{3}$ are by law required to refuse to make loans on security of "encumbered" titles. Moreover the priority which subsequent tax liens have over earlier real estate mortgages forces these lenders, even though they have made a loan on a clear title, to "police" the mortgagor-land-owner's management of the property to see to it that he pays the tax. In short the real property tax is in large part "enforced" by private enterprise itself because of the impact of the tax on the real estate market. One need compare only the most conservative estimates in large cities of the percentage of lots complying with the real property tax with the percentage of lots complying with planning laws to note the effectiveness of this method of enforcement.

It is the purpose of this paper to examine the existence of and the possibility of similar and other methods of private enforcement of planning legislation. Jurisprudentially it might be said that all enforcement is by the state. The rule of law that the lien for the unpaid property tax is an encumbrance and that insurance companies may not invest in a mortgage on such property is as much a rule of government as the rule that a building code violation subjects the owner to a $\$ 2.00$ per day fine. But, for present purposes, we treat as "public" enforcement any judicial or administrative proceeding initiated against land or its owner by appropriate government officials to secure enforcement of planning laws. ${ }^{4}$ We treat with three types of "private" enforcement in this paper: ( $\mathrm{I}$ ) enforcement arising from the operation of the real estate market as a result of some rule of law affecting the commodity, marketing practices or institutions; (2) enforcement by means of direct legal proceedings commenced by private citizens or associations of citizens against the violators of city planning legislation; and (3) enforcement by means of initiation of public prosecutions by private persons. Types two and three are most nearly analogous to "public" enforcement since but for a difference in initiator of the legal proceedings the type of relief is substantially the same.

\section{I}

Enforcement Through Utmuzation of the Market and Its Institutions

Planning legislation is complied with the more, the more it affects the self-interest of landowners. Thus if fines are large enough and certain enough, it may be unprofitable for an owner not to comply. But the controls on the market considered in this section of the paper operate more directly on marketing forces and practices

\footnotetext{
${ }^{3}$ See Ernest Mc. Fisher, Urban Real Estate Markets: Characteristics and Financing 66 (1951) for volume of mortgage loans by type of lender. The institutions mentioned in the text furnish 73.2 per cent of mortgage capital in the real estate market.

"For a detailed treatment of many types of public enforcement, see MicGoldrick, Gruubard, AND Horowitz, op. cit. stupra note 2, c. 8 .
} 
rather than directly on the owner and through him on the market. Controls considered here directly affect the merchantability of the product.

Violation of planning legislation may make the landowner's product less merchantable, by: (A) threatening the income forthcoming from the property; (B) making it difficult to adhere to established management and marketing practices; and $(C)$ rendering the title defective so that buyers and lenders will not or cannot purchase an interest in his commodity.

\section{A. Threatening the Income from the Property}

The most direct impact on income from violating property is that found in statutes such as Section 302 of the New York Multiple Dwelling Law which provide that a tenant in a building without certain certificates need not pay rent and that a landlord cannot evict him for such non-payment. This statutory remedy is a radical departure from the common law where the tenant's only excuse for non-payment of rent arises from a "constructive eviction," that is, the premises become so untenantable through a violation of a landlord's duty, that the tenant is obliged to remove himself from the premises and is excused thereafter from paying rent. ${ }^{5}$ It is suspected that compliance with this type of planning law would come with unparalleled speed if the occupants of violating builders were armed with an effective club of continued occupancy without rent payments until the owner razed the building or obeyed the statute. However this New York statutory remedy has not been effective. It is not available for violations generally but only for failure to have a certificate of occupancy. But its big weakness stems from a misconception of the nature of the rental market in substandard housing. The landlord is "outlawed" from court only for actions for non-payment of rent. Since most tenancies in substandard housing are of relatively short term the landlord can, by appropriate notice, terminate the tenancy shortly after the tenant refuses to pay rent and thereafter evict the nonpaying tenant even though the building violates the law. This substantially reduces the risk of loss of income to the landlord, particularly if there is a brisk demand for this type of housing. ${ }^{6}$

The income from rental property may be affected by another type of law. ${ }^{7}$ In some jurisdictions, such as California, a tenant can, on his own motion, repair a sub-

\footnotetext{
-See generally on this doctrine, 2 Richard R. Powell, The Law of Real Property \$227 (1950).

- Until I950 there was an additional threat to the landlord. He could not, under Sec. 260 of the Multiple Dwelling Law, dispossess a tenant in a violating building who refused to pay a rent larger than the lowest rent charged for any month between September 1937 and March 1938. After many extensions this remedy was allowed to expire in 1950 .

In Detroit Hits Code Violators in Pocketbooks With Old Law, 12 J. Housing 6r (1955), it is reported that a Detroit ordinance prohibiting collection of rent in buildings as to which notice to vacate has been served is now being enforced. For statutes similar to that in the text, see ConN. Gen. Stat. tit. 30, c. 196, $\S 4080$ (1949); Iowa Code An. \$413.106 (I954); Mich. Stat. AnN. \$5.287 (I949). See generally, 144 A.L.R. 259 (1943).

"States which impose tort liability for breach of the statutory duty of repair also indirectly "threaten" the income of a non-complying owner by increasing his insurance risk. See 2 Powels, op. cit. stipra note $5, \$ 238$.
} 
standard building and withhold rent until reimbursed for his expenditures. ${ }^{8}$ This remedy is also a substantial change from traditional landlord and tenant doctrines but it is ineffective because it is subject to contract between landlord and tenant.

B. Making It Difficult to Adhere to Established Practices of

Property Management and Marketing

A penalty for violation of planning legislation may "upset" established practices in property management. Thus many housing and building codes provide that the statutory fine or imprisonment falls on the rent collector, management agent, contractor, and architect as well as the owner. ${ }^{9}$ Other practices on which planning might impinge are those concerning insurance, mortgages, and marketing by reference to a map.

Violations of planning legislation may affect an insurance policy in several ways. Thus some violations may cause a policy to be avoided under a clause making a policy void in case of ordinance violations; or the violation may result in an "increased hazard" exception to loss under the policy; or it may avoid or suspend the policy on a theory of illegal use; or the violation may cause a breach of warranty. ${ }^{10}$ The above possibilities exist only when the violation has some relation to risk (e.g., violation of electrical code) and the reluctance of courts to construe policies to except losses which have occurred makes this method of enforcement not too effective. A stronger possibility would arise from inducing insurance companies to cancel or threaten to cancel policies on violating properties. In some communities the method is used with respect to fire laws. To compel the insurance industry to participate would appear to require legislation in most states. Where the state supervisory agency has power to prescribe a standard policy form, a cooperating insurance commissioner might be prevailed upon to insert a cancellation or avoidance clause in the policy. But the supervisory agency does not, in normal cases, seem to extend to compelling companies to establish a practice of cancellation on notification of a violation or to compelling establishment of a differential rate classification for violating or non-violating properties. ${ }^{11}$

The threat of cancellation whether obtained by agreement or compulsion is effective, however, because of the impact of cancellation on another private agencythe mortgagee. Many mortgages provide for a default and possible acceleration of the mortgage if the mortgagor fails to carry insurance. ${ }^{12}$

${ }^{8}$ Sec Cal. Civ. Code $\$ 1942$ (1949); Mont. Rev. Code tit. 42, \$42-202 (1947); N.D. Rev. Code c. $47, \$ 47-1613$ (1943); OKLA. STAT. tit. 41, \$32 (195I); and S.D. CODE $\$ 38.0410$ (1939).

See McGoldorick, GraUbard, and Horowitz, op. cit. supra note 4, at 458; N.Y. MultTple DwellING LAw $\S_{305}$ (1946).

${ }^{10}$ For an "increase in hazard" clause, see New York Standard Fire Policy, N.Y. INs. LAw \$168(5) (1949). See generally on the defenses of the insurer relating to violations, VANCE on INsurance \$146 (3rd ed. I95I); John A. Appleman, Insurance Law aNd Practice \$2871 (altcration of premises), $\$ 2878$ (change in class of occupation and use), and $\$ 2880$ (illegal use) (1941).

${ }^{11}$ Sec N.Y. INS. LAW $\$ 169$ (x949) on power to prescribe policy forms. For rating powers see N.Y. INs. LAw $\$ \$ 8 I-189$ (I 949 ).

${ }^{12}$ For some institutional lenders this provision is required for eligibility of mortgage. Sec, e.g., Illinois Building and Loan Law, InL. Riv. StAT. c. 32, \$231(b) (1951). 
Another established management practice is the use of borrowed capital which is repaid to the creditor at stated intervals in the future. In New York by statute and in many states by mortgage clause a mortgagee has power to accelerate payments of mortgage principal in case of violation of municipal ordinances applicable to the mortgaged property. ${ }^{13}$ These clauses tend to secure compliance with the local ordinance only to the extent that mortgagees establish a practice of exercising their contractual or statutory power of declaring the mortgage in default if violations are not cleared up. If such a practice were firmly established there is no doubt that this would seriously interfere with established management practices of landowners and could compel compliance. In some communities property owners' associations have a policy of reporting violations to mortgagees of record and this has frequently induced compliance.

Without a certain amount of compulsion or obvious self interest it is unlikely that a mortgage lender will exercise his power of acceleration on a mortgage on which the mortgagor is making regular payments, perhaps only because of the increased income resulting from his violation of planning laws. While the journals and books of the mortgage industry abound with articles and advice about the necessity of "servicing" a mortgage by periodic inspections to see to it that the mortgagor does not "milk" the property by causing excessive deterioration, the mortgage lender does not yet realize that the building department could be made an adjunct of his own servicing department by giving him the reports of the government inspectors.

Perhaps the planning legislation which has the clearest recognition of the use of market forces to obtain enforcement is the subdivision control legislation. While most subdivision control laws have various forms of criminal penalties, the central theme of enforcement is that unapproved plats of a subdivision are not entitled to recordation. ${ }^{14}$ The assumption of such a "penalty" seems to be that the custom of describing property by reference to maps is so strong and so convenient that the subdivider will submit his map for approval even though there is in most such laws a technical "loop-hole" permitting use of a metes and bounds description. If the recorder does his job there is something more than a mere threat of a fine to a subdivider for using an unapproved map-he cannot use the short-hand method of describing his land which the marketing institutions approve.

Many subdivision laws make further use of the market as a method of enforcement. Some provide that an unapproved map even though mistakenly filed is not a matter of record; that sales from such maps may be avoided by purchasers; that public improvements cannot be located by municipal governments in unofficial streets (which streets on unapproved maps are said to be); and that building permits will not be issued for buildings facing on unapproved streets. ${ }^{15}$

${ }^{13}$ N.Y. MUltiple Dwelling Law $\$ 302$ (1946).

"See generally, H. W. Lautner, Subdivision Regutations 28 (I94I).

${ }^{10}$ See, e.g., Maryland-Washington Regional District Subdivision Control Law, Md. Laws 1943, c. 992, \$2, as amended. 
Several weaknesses appear however in this method of enforcement. One is that the burden of many of the penalties may fall on one of the classes of persons which the subdivision control ordinance is supposed to protect from his own folly. One purpose of such legislation is to protect a buyer from hardship resulting when he improvidently relies on assurances of speculative developers about the nature of the subdivision. Giving this buyer the power to avoid his contract assumes that he has a knowledge of his legal rights after breach which it is assumed he did not have before he purchased, and the power of the city to withhold building permits for buildings on unapproved lots may put the full onus for noncompliance on this same betrayed buyer. ${ }^{16}$ To the extent however that the merchandizing of a subdivision requires a developer to market a finished product rather than a vacant lot, the onus of compliance for purposes of building permits is put upon the developer.

A further weakness in this legislation arises from the fact that the territorial limits of the recording office include units of government which have and some which do not have this type of ordinance and there is no effective procedure in most states to bring home to the recorder the idea that in some areas he must not record plats without planning approval and with respect to other areas he may. This has resulted in considerable error on the part of recorders in recording maps which should not be recorded. ${ }^{17}$

Finally the legislation did not clearly establish that title to lots in an unapproved subdivision is unmarketable.

One advantage of this type of legislation is that it appears to be the practice of institutional lenders to insist on proof of compliance with the subdivision law before they will commit themselves to a developer to loan on security of housing constructed in the subdivision. Thus both the Federal Housing Administration and the Veteran's Administration refuse to give a commitment for insured mortgages on property in a new subdivision without proof of compliance with the subdivision laws. ${ }^{18}$

Thus the marketing practice of conveying by reference to a recorded map and the practice of the subdivider obtaining commitments of mortgages for his prospective mortgages tend to insure compliance with the subdivision control laws in urban areas.

\section{Violations of Planning Legislation and Marketable Title}

If violations of planning legislation render the title defective, we have perhaps the most significant method of private enforcement yet discussed. If such is the rule then we have something which tends to produce some compliance every time the property is sold commercially or a mortgage loan placed on the property.

Does a violation of planning legislation render the title defective? The case

${ }^{10}$ Note, Wrongful Subdivision Approval by the Plan Commission-Remedies of the Buyer and City, 29 IND. L. J. 408 (1954); Note, Land Subdivision Control, 65 Harv. L. Rev. 1226 (1952).

${ }^{17}$ Melli, Subdivision Control in Wisconsin, [1953] Wrs. L. REv. 389.

${ }^{18}$ International City Managers' Ass'n, Local Planning Administration 255 (2d ed. 1948) reports FHA refuses to issue commitments on houses on unapproved lots. Sce, e.g., FHA, Minimum Property Requirements for Chicago District. 
law would seem to answer this question in the affirmative. ${ }^{19}$ If a subdivision control law provides that a plat improperly recorded is not a matter of record it would seem that an improperly recorded plat is a matter of title ${ }^{20}$ just as absence of a properly acknowledged deed (although recorded) may be a matter of title. Certainly this would seem to be the rule in so far as the vendor's obligation is to convey a record title because absence of a recorded map would mean that the purchaser's title with respect to easements in streets and other public places shown on the map would be unrecorded even though the description of the lot by reference to an unrecorded plat is a sufficient description to convey (as between grantor and grantee).

The Hocking ${ }^{21}$ case from California does not seem to be contrary to this conclusion. In that case an insured who had purchased a lot in a subdivision as to which the map was erroneously approved by the city council sought to hold his title insurance company on his title policy insuring marketability, after he discovered that in spite of what appeared to be an approved plat, the city officials would not give him a building permit to build on his lots. The majority of the Supreme Court, over a sharp dissent, held that the claim was not covered by the policy. Several grounds not involving our problem were available for the decision. The Court said that under the terms of the policy loss had not been established even though the defect was a matter of title; it said that plaintiff was not really objecting to title but to the quality of the premises. In so far as the majority meant by this that the refusal to issue a building permit was not a defect of title there may be no quarrel with the decision. But as the dissent pointed out there was a title defect if a lot owner purchased a lot which did not face on a public street or appurtenant to which there were easements in his favor not of record. ${ }^{22}$ The majority pointed to language in the California statute which seemed to say that if the approval of the city council was endorsed on the map, as it was, the map was "duly recorded," 23 thus implying that if the map had been unrecorded or recorded without city council approval a title defect would have existed. That part of the statute, not referred to by the majority, giving the purchaser or the government power to cancel the sale would also seem to create a defective title. ${ }^{24}$

An opinion of the Attorney General of Wisconsin ${ }^{25}$ seems to hold that a violation of a subdivision control statute does not render the title defective but in Massachusetts the Land Court refuses to register title to lots in an unapproved sub-

${ }^{10}$ See Dunham, Effect of Violations of Building Covenants and of Zoning Ordinances on Title, 27 Rockr Mr. L. REv. - (1955).

${ }^{20}$ Cleveland v. Bergen Bldg. \& Imp. Co., 55 Atl. 117 (N.J. Ct. Ch. 1903); Morris v. Avondale Heights Co., $218 \mathrm{Ky} .356,291$ S.W. 752 (1926). See 3 AMerican LaW of Property \$12.124 (Casner ed. 1952) and cases cited.

${ }^{21}$ Hocking v. Title Insurance \& Trust Co., 37 Cal.2d 644, 234 P.2d 625 (I95I), commented upon

in 4 AnNual Survey of Californta Law, 1951-1952 222.

${ }_{22}^{2}$ See cases cited in note 20 , supra.

${ }^{23}$ Cal. Bus. and Prof. Code c. 2, art. Io, \$II628 (195I).

34 Clemons v. City of Los Angeles, 36 Cal.2d 95, 216 P.2d I (1950). But cf. Land Title, C. N. Marques, 37 Hawaii 260 (1945).

${ }^{25} 34$ Ors. Atr'y Gen. Wis. 290 (I945). 
division. ${ }^{26}$ To avoid this doubt clarifying legislation is needed in most states. ${ }^{27}$

"Violations" of official street map ordinances-that is buildings built in the beds of mapped but unopened streets without permit-seem to render the title defective, ${ }^{28}$ as do violations of zoning ordinances. ${ }^{29}$. Violations of building and housing codes would seem to be in the same category as violations of zoning ordinances, although the New York cases seem to distinguish zoning and restrictive covenant violations from building and housing code violations. ${ }^{30}$ However, it appears to be the practice of title companies in New York to report, at the time they prepare a title report, on all uncorrected violations of record in the building department. ${ }^{31}$ This would seem to indicate some practice at least treating this type of violation as a matter of title.

While the above may be the result of the cases, this assumes significance for our purposes only if the title examining industry reports these violations as they do the real property tax lien and if those forces in the market interested in the quality of the seller's title take into account violations of planning laws in their own actions. There is very little evidence that the title examining industry and the institutions of the market treat these matters as matters of title.

Abstractors usually examine only the "record title" and lawyers examining abstracts base their opinions only on the record therein disclosed. With the exception of the status of the subdivision map which is a matter of record; building code violations as to which "notices" have been sent and are on file in the office of the building department; and master street plan maps which are on file in some appropriate city office-most violations cannot possibly be said to be a matter of record but are only matters discoverable on some kind of inspection or survey. Surveyors seem to show lot lines and any violation of set-back lines in zoning ordinances on their surveys but do not ordinarily show violations of other bulk restrictions (e.g., height) and never a violation of a use restriction of a zoning ordinance. The usual inspection report seems to be directed to mechanics liens and "possessory" claims and not to obvious violations of planning legislation. ${ }^{32}$ Thus, most of the title industry concerned with records, inspections, and surveys do not seem to pick-up violations in these customary title reports.

\footnotetext{
${ }^{20}$ See Mass. Ann. Laws c. 4r, §8IFF (1954 Cum. Supp.). Before this statute clarificd the situation there was considerable shock at this conclusion among conveyancers. See Tyler, Pitfalls in Tille Examinations, 35 Mass. L. Q. 21, 26 (Sept. 1950).

${ }^{27}$ See Mass. Laws 1953, c. $674, \$ 7$, amending c. $4 \mathrm{I}, \$ 8 \mathrm{I}$, Mass. ANN. Laws.

${ }^{28}$ Petterson v. Radspi Realty and Coal Corp., 290 N.Y. 645, 49 N.E.2d 615 (1943); Bibber v. Weber, 102 N.Y.S.2d 945 (Sp. Term 195I); Agliata v. D'Agostino, N.Y.L.J., May 6, 1953, p. 1524, col. I.

${ }^{29}$ Carlish v. Salt, [1906] I Ch. 335; Moyer v. De Vincentis Construction Co., ro7 Pa. Super. 588, I64 Atl. III (1933); Lohmeyer v. Bower, 170 Kan. 442, 227 P.2d I02 (195I).

${ }^{30}$ Woodenbury v. Spier, I22 App. Div. 396, 106 N.Y. Supp. 817 (2d Dep't 1907). See also Millman v. Swan, r4i Va. 312, 127 S.E. I66 (1925).

${ }^{81}$ Speech of William Wolfman, Counsel, New York Title Guaranty \& Trust Co., before the Round Table on Property, at the annual meeting of the Association of American Law Schools, in New York City, Dec. 28-30, 1954. In Detroit, notices of violations are now being recorded in the realty records. See Detroit Hits Code Violators in Pocketbooks With Old Law, 12 J. Housing 61 (1955).

${ }^{32} \mathrm{See}$, e.g., "Certificate of Inspection and Possession" required by Regulations for the Preparation of Title Evidence in Land Acquisition by the United States.
} 
Furthermore, title insurance companies, even those purporting to insure marketability, usually attempt to limit their liability so as to exclude "governmental acts" and the violation thereof. ${ }^{33}$

The American Title Association Loan Policy which is available only to lenders, and is not issued everywhere, purports to be an exceptionless policy but it also excludes from its coverage insurance "against action by any governmental agency for the purpose of regulating occupancy or use of said land or any building or structure thereon." It is not clear, however, that this relieves the title insurance company issuing this policy from liability in the situation where zoning law enforcement proceedings are commenced by private citizens instead of by a governmental agency.

Nor do institutional lenders and their government supervisors insist on the position taken by the cases. As far as is known there are no statutes which expressly make a loan on security of land in violation of planning legislation an ineligible investment for the regulated investor. Neither are there any statutes which in express terms require a marketable title for an eligible investment. The statutes regulating banks, building and loan associations, insurance companies, and other regulated investors require the loan either to be secured by a "first" mortgage (or lien $)^{34}$ or to be one on security of "unencumbered"35 real estate or sometimes require that the security be both a "first lien" and upon "unencumbered real estate."36 While it has been suggested that this language does not compel the institutional lender to insist on marketable title ${ }^{37}$ it is doubtful that this conclusion can be maintained. Unless an "encumbrance" is considered only a monetary lien, those statutes which require unencumbered real estate would clearly make ineligible investments in loans secured by mortgages on land encumbered with easements, encroachments, and other "encumbrances." A violation of a zoning ordinance which subjects the purchaser to the hazards of litigation would seem to be as much an encumbrance as an encroachment. That an encumbrance embraces most of the customary title defects seems to be the common understanding for the word. ${ }^{38}$

The "first lien" statutes present a slightly different problem of construction, however, since technically property subject to an easement of way, for example, could

${ }^{33}$ Thus the title insurance policy in the Hocking case, supra note $2 \mathrm{r}$, excepted from coverage "any governmental act or regulations restricting, regulating or prohibiting the occupancy or use of said land or any building or structure thereon."

But it is reported that some title policies now insure against zoning violations. Henley, Report of Committee on Standard Forms, 28 TirLe News 25 (February, 1949).

${ }^{34}$ See, e.g., Ill. Rev. Stat. c. 73, $\$ 737$ (I)(e) (I95I) (life insurance companies); Col. Rev. Stat. §14-I-33 (1953) (banks); OHIo REv. CODE $\$$ Iro5.19 and Irog.08 (1953) (banks and building and loan associations); Mass. ANN. Laws c. 168, $\$ 54$ (savings banks); Federal Reserve Act, 38 STAT. 273 (1913), as amended, 12 U.S.C. \$37I (1952 Supp.); Servicemen's Readjustment Act, 58 STAT. 129I (rg44), as amended, 38 U.S.C. $\$ 694$ (r952 Supp.).

${ }^{36}$ Sec, e.g., Mass. ANn. Laws, c. $175, \$ 63$ (1948); N.J. Rev. Stat. \$17:21-I(c) (1937).

${ }^{30}$ Caz. Ins. Code \$1176 (1950); Ore. Rev. Stat. \$738.250 (1953).

${ }^{37}$ Reeves, Guaranteming Marketability of Tithes to Real Estate i 8 (I95I) (unpublished, for use of Chicago Title and Trust Co.).

${ }^{88}$ Thus many insurance statutes provide that building restrictions, leases, and liens for current taxes are not to be encumbrances within the meaning of the statute. N.Y. INS. LAw \$8I(6) (1949). 
qualify as property on which the mortgage would be a "first lien." But again something more than a technical first lien is the common understanding. Perhaps this results from the fiduciary nature of the investor's duty which presumably requires him to be "prudent" even within the permissible field. Trustees are required by the "prudent" requirement to invest in mortgages on land as to which the title is marketable. ${ }^{39}$

The mortgage industry practice is not clear ${ }^{40}$ but tends, as does the policy of the government supervisors, ${ }^{41}$ to accept a title insurance policy as complete proof of eligibility of title. The Veterans Administration's regulation under a "first lien statute" best represents the prevailing attitude: title to the mortgaged land satisfies the requirements if it is "acceptable to informed buyers, title companies and attorneys generally in the community in which the property is located."42

The practice of two United States government agencies insuring mortgages on urban real estate is revealing in connection with our problem. As indicated earlier both the Federal Housing Administration (FHA) and the Veterans Administration (VA), before they commit themselves to insure loans in a newly established development, do require the applicant (developer or builder) to submit proof of compliance with local subdivision and zoning laws. ${ }^{43}$ But this is the practice of neither agency when either old housing or isolated new construction is involved.

Thus, the Solicitor of the VA has ruled that a violation of a zoning ordinance does not destroy eligibility of the security but he admonishes the appraisers to take this into account in valuing the property. ${ }^{44}$ In short, the VA, under its statutory authority, limits its function to that of seeing to it that the veteran and the Federal Government get value for their investments; it is not concerned with or responsible to the community in which the veteran purchases.

The FHA operating under a similar type of guaranty legislation seems to draw a line in its regulations between "big" and "little" business. If a developer is seeking approval for loans on housing in a subdivision, on multiple dwellings of twelve or more units under the Section 207 program or on a co-operative housing project (Section $2 \times 3$ ), proof must be submitted of compliance with local government regulations. ${ }^{45}$ If, however, the application is for insurance of a loan on a single one-to(1907).

${ }^{39}$ Gilbert v. Kolb, 85 Md. 627, 37 Atl. 423 (1897); In re Roach's Estate, 50 Ore. 179, 92 Pac. 118

${ }^{30}$ Letters to the author from general counsel of six large life insurance companics indicate that in loans on new construction five of the six companies check for both building and zoning laws. On old buildings only one checked for zoning and building code violations, and one said their "appraisers" took this into account.

"In letters to the author from the Insurance Commissioners of Connecticut, Illinois, New Jersey, and New York only the latter expected the title insurance policy to show zoning violations. Illinois refused even to see a problem as it accepts title insurance as complete proof apparently even for matters against which title insurance does not insure.

${ }^{2} 38$ CODE Fed. Reg. $\$ 36.4350$ (I) (a) (Cum. Supp. 1954). This was added June 12, 1950, 15 FED. REg. 4398 (1950).

${ }^{13}$ See note i 8 supra.

1 VA Sol. Op. No. 22-49 (1949); id., 186-47 (1947).

${ }^{45}$ Reg. 232 (for Sec. 207 mortgages on multi-family housing), and Reg. 241 (for Sec. 213 mort- 
four family unit (Section 203), on an individual dwelling unit in a co-operative project (Section 213), on property in an urban renewal area of a one-to-four family type (Section 220), or for a Title I home improvement loan, the regulations do not require, as a condition of insurance, any proof as to compliance with local planning ordinances. ${ }^{46}$ Since the loan is insured, there is of course no incentive on the lender to undertake his own investigation as to such violations. Indeed, most statutes establishing title and other standards for eligible mortgages specifically remove almost all restraints if the VA or FHA insures. ${ }^{47}$

In the light of the purposes of the VA loan system it may not be improper for the VA to ignore local planning; his job was to get the veteran a home-at least the VA can say it was no more than that. But the same cannot be said of the FHA. Almost since the original National Housing Act and at least since the Housing Act of I949, the Federal Government program of insured loans and grants for housing has had a planning element among its objectives. Since I949 some kinds of federal aid to municipalities have been conditioned on the performance record of the local community in having adequate planning and enforcement. ${ }^{48}$ The 1954 Act requires, as a condition to certain grants, loans, and mortgage insurance, that a city have a "positive" program for prevention of blight and it establishes a new objective-the rehabilitation of older areas of the city. ${ }^{49}$ It seems highly indefensible for the FHA, particularly in areas set aside for urban renewal, to require no check on violations caused by home improvements under Title I nor on violations encouraged by liberal loan policies on old one-to-four family buildings. On the one hand, the Housing and Home Finance Administration is chiding cities for not enforcing their planning laws and threatening if they do not improve, to withhold grants in aid necessary to help the cities "renew" or "redevelop" deteriorated parts of the city; but, on the other hand, it is telling local banks and builders that the FHA does not care whether they loan, at government risk, to private owners who illegally convert or repair old buildings, thus adding to the blighted conditions in the very cities the FHA says it is trying to save. Almost the best proof city officials could offer the administrator of the urban renewal program that the city has a workable program to stop blight would be to give him a copy of a memorandum from the administrator of the housing mortgage insurance program instructing

gages on cooperative housing projects). Reg. 280 also provided for proof of zoning compliance in the now expired Sec. 608 program. All of these regulations are in 24 Code Fed. Regs. (Cum. Supp. 1954).

${ }^{10}$ Reg. 221 (for Sec. 203 mortgages on one-to-four family housing); Reg. 243 (for individual mortgages released from lien of cooperative projat mortgage); Reg. $26 \mathrm{r}$ (for $\mathrm{I}-\mathrm{x}$ I family dwellings in rehabilitation area under Sec. 220); and Reg. $20 x$ (alteration, repair and improvement including conversion of existing housing-Title I loans). All are found in 24 CODE FED. REgs. (Cum. Supp. r954)

It is true however that in Section 203 loans on new construction FHA Manual, Minimum Property Requirements for Properties, specifies that the development shall conform to local zoning, building and construction laws. This is not required for existing construction.

${ }^{47}$ See, e.g., N.Y. INs. LAw $\$ 8 \mathrm{I}(6)$ (1949).

${ }^{48}$ See Title I, Housing Act of r949, 63 STAT. $4 \mathrm{r} 3$ (1949), as amended, 42 U.S.C. \$r $44 \mathrm{r}$ et seq. (1952 Supp.).

${ }^{40}$ Section 303 of Housing Act of I954, 68 STAT. 623, 42 U.S.C.A. \$I45I (I954 Supp.). 
lenders and builders that insurance would no longer be available for loans without proof of compliance with most, if not all, local planning laws.

It is no answer to this problem to instruct the appraisers to take "violations" into account in establishing value because often the illegal use is an intensification of use which may well increase the value of the property. Nor is it a defense of the FHA that violations are difficult to police. As a minimum the same kind of certificate or affidavit from the city or local lender as is used in other areas of FHA supervision could be required. ${ }^{50}$

Before this method of enforcement is fully embraced by city planners, some of the possible consequences should be noted. If planning violations are to be made such a title defect that the institutions of the market must take cognizance of such violations, it would seem that these private institutions are entitled to insist on at least three conditions: ( $\mathrm{I}$ ) that there be a machinery available whereby they can obtain from the enforcing officials a definitive statement that there is or is not a violation as of a particular date; (2) a statute of limitations so that if the planning violation is not caught by the city official within a specified time the property is freed from the regulation; and (3) an adequate public record of the violations or restrictions available to title examiners and indexed in a manner to which the examining industry is accustomed.

While there seems to be some statutory development toward imposing a statute of limitations, ${ }^{51}$ the present situation is almost intolerable on the other points. In subdivision regulations, for example, state enabling legislation usually authorizes municipalities to impose such regulation on land within its municipal boundaries and sometimes on an extra-territorial area as well. Land records, kept by larger units of government-usually counties-cover both areas without such legislation and areas with it. Under present laws there is nothing in the county office containing the land records to tell the examiner whether a subdivision map on file in that office should have been approved or not, or whether the approval noted thereon was by the proper officials, or whether the officials can go behind their own approval and later upset it. ${ }^{52}$ Likewise, municipal offices charged with enforcement of zoning, building codes, and housing laws have in many cities no adequate records of violaI954).

${ }^{50}$ See, e.g., certificate concerning prevailing wage, 24 Code FEd. REgs. $\$ 232.19$ (d)(4) (Cum. Supp.

${ }_{51}$ See N.Y. Gen. City LAw $\$ 35$-a (I954 Cum. Supp.): if no action commenced within fifteen ycars to revoke building permit erroneously issued for building in bed of mapped strect, permit is valid. Added by N.Y. Laws 1954, c. 775. See also Mass. Laws ANN. c. 4I, \$8IY-one year statute of limitations on proceedings against violation of subdivision law.

52 In 1953 Massachusetts made provision in its subdivision law for many of these problems. Mass. Laws r953, c. 674. The subdivision ordinance is not effective until register of deeds is notified of its existence; the Planning Board is required to record its regulations and also to state on request whether a particular area is subject to regulation or not. N.Y. Multiple Dwelling Law $\$ 301$ (5) (1946) provides that a certificate or record in building department may be relicd upon by any good faith purchaser or lender.

In Seat v. Louisville \& Jefferson County Land Co., 219 Ky. 418, 293 S.W. 986 (1927) only by taking "judicial notice" of absence of a planning ordinance in Louisville was the court able to determine whether a plat was recorded. 
tions and notices which can be checked by the title examiner. Finally, the street plan ordinances, as well as the zoning ordinance, are overly optimistic about future development. There should be some provision, just as there is for restrictive covenants, whereby these ordinances prospective in operation cease to be effective after a period of time if development does not take place.

$\mathrm{Up}_{\mathrm{p}}$ to this point we have been concerned with the existence of an encumbrance at the time of a transfer of some interest in land. The real property tax has an additional impact on title-that tax for any year is by law made a lien senior to that of an earlier mortgage so that a mortgage, an eligible investment when made, may become ineligible by subsequent conduct of the mortgagor. This induces lending institutions to police their mortgagors. Absent a statute making a subsequent violation an encumbrance on the title under a mortgage such a result would not occur with respect to planning violations.

One such attempt was made in the field of planning. New York, on the analogy of taxes and special assessments, attempted to make the city's lien for improvements on private property made by the city in order to bring the building into compliance, senior to existing mortgages. This, if effective, would of course put the mortgagee clearly in the position of being policeman for the city. There would be no constitutional objection to such a statute if it were made applicable only to mortgages executed after its effective date and as to violations thereafter occurring. It was held unconstitutional, however, as to a mortgage which antedated the statute. ${ }^{53}$ The court was impressed with the argument that while a mortgagor could avoid the lien as to his interest by closing up the building instead of permitting its repair, the mortgagee had no power to do this until after foreclosure and, in the meantime, an agreement between the city and the mortgagor could subordinate a mortgage to a lien for improvements which would otherwise be junior to the mortgage. Subsequent developments in the constitutional concept of "due process" may have weakened the authority of this case. ${ }^{54}$

Another route to the same end has been suggested in Chicago. ${ }^{55}$ In an equity proceeding to abate a nuisance, the petitioner can ask for the appointment of a receiver to abate the nuisance. On appointment, the receiver's obligations incurred in abating the nuisance (making the repairs) would be senior to the lien of the mortgagee. $^{56}$ Whenever a violation results in a nuisance, this concept of equity receiverships gives the city an additional weapon to induce the mortgagee to police the management of the property by the mortgagor.

${ }^{53}$ Central Savings Bank v. City of New York, 279 N.Y. 266, 18 N.E.2d I5 I (1938), cert. denied, 306 U.S. 66I (1938). See Note, 39 Col. L. REv. 889 (1939), for history of this statute.

"Thus giving the state a prior lien on railroad property for the railroad's share of the cost of grade-crossing elimination has been upheld against claims under earlier mortgages. New York v. Gebhardt, I5I F.2d 802 (2d Cir. I945).

Et 20 Ops. Corp. Counsel of Chicago I67, at I74-177 (No. roog9).

co Jas. L. High, A Treatise on the Law of Receivers $\$ 796$ (3rd ed. I894); i Pomerot, Equitable Remedies \$220 (I905). Cf. New York Dock Co. v. Steamship Poznan, 274 U.S. Ir7, at I2I (I927); Attorney General v. Vigor, ix Ves. 563, 32 Eng. R'ep. 1207 (Ch. 1805). 


\section{Enforcement by Direct Action by Private Persons}

The most frequently thought of method of enforcement other than public enforcement is private action by a private citizen to compel a violator of planning laws to comply. This method may be authorized in the enabling legislation ${ }^{67}$ or may be available by application of equity principles.

If the planning legislation declares a violation to be a "public nuisance" this neither detracts from, nor adds to the power of the citizen to seek an injunction against the same violation. Neither does the equity maxim that it will not enjoin violation of the criminal law detract from whatever right the plaintiff has. Absent express statutory authority, the right of a private citizen to seek an injunction against a violator of city planning is based on the theory of private nuisance-i.e., action of the defendant which has caused "special damage" to the plaintiff.

On this theory it is difficult to imagine a situation where private enforcement of subdivision control law or the master street plan could be obtained. ${ }^{58}$ With respect to zoning, the case law fairly consistently permits a neighboring property owner to seek an injunction against violation of the zoning ordinance. ${ }^{50}$ The problem for the plaintiff, in any type of planning legislation, is that of establishing "special damage" different from damage to the public generally. Sometimes this issue is avoided by the court saying that the zoning ordinance was passed for the benefit of the neighboring property owner or that there is a presumption of "special damage" to neighboring property owners. ${ }^{60}$ This avoids the question whether the damage to the plaintiff must be different in kind or only in degree from that suffered by the public at large since it is well established that a private citizen cannot compel compliance with a law to protect himself from damage which he suffers as a member of the public. Since one of the major objectives of a zoning ordinance is to prevent commingling of "incompatible" uses it is not difficult for the plaintiff to establish some special damage arising from proximity. ${ }^{01}$ This is more difficult, in theory, where the objective of the zoning ordinance is something other than orderliness of uses. Thus it might be difficult for a neighboring property owner to enjoin a violation of a section of the zoning ordinance whose objective is to control the intensity of the use of the city's services. However, the case law has not drawn this fine a line in most states and if the plaintiff's property is near the defendant's he is permitted to enjoin the violation almost on that fact alone.

A much more difficult question is private enforcement of housing and building

${ }^{87}$ See, e.g., OHio. Rev. Code \$303.24 (I953); Ill. Rev. STat. c. 24, \$73-9 (I953).

${ }^{58}$ Massachusetts has given ten taxpayers the right to enforce subdivision control laws. Mass. ANN. Laws c. $4 \mathrm{x}, \S 8 \mathrm{IY}\left(\mathrm{I} 95^{2}\right)$.

59 The leading case is Welton v. 40 E. Oak St. Bldg. Corp., 70 F.2d 377 (7th Cir. 1934), cert. denied, 293 U.S. 590 (1934). See 2 E. C. Yokley Zoning Law and Practice \$192 and cases cited (2d cd. I953); 8 McQuillin, Municipal Corporations \$25.343 (3d ed. 1950).

${ }^{\circ 0}$ Welton v. 40 E. Oak St. Bldg. Corp., supra note 59 .

1 See Note, Injunction, Right to Maintain Action for Violation of Zoning Ordinance, 2x B.U.L. REv. 556 (194I). 
codes. Much, if not most, of the provisions of this type of law are designed to protect the health and safety of occupants of the buildings regulated. While such occupants might have the benefit of the special damage rule as applied in the zoning cases, there would be no presumption of special damage entitling the neighboring property owners to seek an injunction. Occasionally a section of the building code, such as the prevention of wooden buildings in certain fire districts, is said to be for the protection of neighboring properties and a private injunction is allowed..$^{92}$

Yet it is the enforcement of these codes which mean so much to stabilization and protection of neighborhoods under any kind of neighborhood conservation program. On analysis it would seem that the problem of private enforcement of these laws is not that of establishing special damage to the plaintiff differing from that suffered by the public but is rather that of establishing a kind of damage recognizable in the law of nuisance. Basically what the neighboring property owner is asserting is that a violation of these codes by the defendant so deteriorates the neighborhood that the violation adversely affects his property values and the satisfactions and enjoyment which having property in this neighborhood gives him. Is this recognizable damage?

The right to be protected in a private nuisance action is the right to quiet and undisturbed enjoyment of neighboring property. If the defendant's conduct impairs the health and comfort of the possessor (e.g., smoke, dust, odor, noise, light, heat), the conduct is easily held to be a nuisance. But in our situation the plaintiff's hurt is analogous to that suffered in the cases dealing with the funeral home, cemetery, bawdy house, contagious disease hospital, and the junk yard as a nuisance. ${ }^{63}$ In planning cases the defendant's conduct rarely affects plaintiff's health or safety-it reduces the satisfactions which he obtains from his own property. Courts have been hesitant in permitting this kind of damage to support a nuisance action, partly out of fear of protecting an unusually sensitive plaintiff against what appears to be reasonable conduct of the defendant and partly out of the difficulty of weighing the relative merit of defendant's and plaintiff's socially desirable uses. Here there can be no doubt as to the unreasonableness of the defendant's conduct and of its non-utility to the public; the public has declared that it does not want defendant's activity to occur, or at least to occur where it is. The court could reduce its worry about protecting super-sensitive plaintiffs if it would make use of the readily available evidence of the extent of the plaintiff's attitude among the public generally. For, if the public generally shares the plaintiff's satisfactions from land use, then the demand for the plaintiff's property in the market will decline and the value of his property will be reduced; if on the other hand there is little agreement with the plaintiff's position, the effect on property values will be much less. If then the plaintiff can establish that defendant's conduct in violating the housing and

${ }^{02}$ People's Gas Co. v. Tyner, 131 Ind. 277, 31 N.E. 59 (1892); Kaufman v. Stein, 138 Ind. 49, 37 N.E. 333 (1894). See I Pomeroy, Equitable Remedies $\$ 478$ (1905).

${ }^{03}$ On nuisance generally, see VI-A AMrRican LAw of Property \$28.25 (r954); Comment, 26 Mích. L. Rev. 942 (1928). 
building code is tending to deteriorate the quality of the neighborhood, he should be entitled to his private action to enforce the codes.

This method of private enforcement has one major disadvantage-equity proceedings are very expensive in most states. If the plaintiff-citizen prevails, he will be awarded some costs but these do not include attorney's fees. ${ }^{64}$ The field of "housing" offers evidence of two methods with which to meet this practical problem.

The first is to award attorney's fees to the successful plaintiff. In 1953 the Illinois legislature, as part of its urban conservation program, authorized the court to award reasonable attorney's fees incurred in the successful prosecution of an injunction against violation of zoning laws. ${ }^{65}$ The Illinois statute is of limited utility because it applies only to zoning, but it is shrewd in conception because it enlists the aid of another private enforcement group-the legal profession.

The second solution to the problem of costs of private injunction actions is to permit the action to be brought by an association or group rather than an individual. Thus, the Housing Act of 1954 prohibiting property on which there is an insured loan to be used for hotel purposes provides in a new section $53^{60}$ of the National Housing Act that "any person owning or operating a hotel" within a specified distance from the violating property or "any group or association of hotel owners or operators" within the same area may bring a suit in federal court without regard to diversity of citizenship to enjoin violation of the insured mortgagor's commitment to FHA and the insured mortgagee. Permitting a neighborhood association to assume responsibility for the suit relieves the property owner of problems of both cost and time. Perhaps a Society for Prevention of Cruelty to Neighborhoods is needed as much as a Society for the Prevention of Cruelty to Animals.

One additional advantage of private actions of this type should be noted. Once the action is commenced, a lis pendens may be filed, ${ }^{67}$ and this is clearly an encumbrance on the title which the title examining industry understands and checks for.

\section{III}

Enforcement by Means of Initiation of Public Prosecutions by Private Persons

Of course, one of the most common methods of both public and private enforcement is complaint to the public officials by a private citizen followed by appropriate proceedings initiated by the public agencies. Sometimes the private citizen can do more than this-he may set the official machinery into motion. Thus, he may on occasion be able to bring mandamus against an official to compel him to enforce the planning laws. It would seem that the basis of such an action is substantially the same as the basis of the private injunction mentioned above. ${ }^{68}$

\footnotetext{
${ }^{6}$ But cf. Walter v. Danisch, 133 N.J.Eq. 127, 29 A.2d 897 (Ct. Err. \& App. 1943) where plaintiff was awarded attorney's fees on an award of a mandatory injunction.

${ }^{\text {o5 }}$ ILL. Rev. Stat. c. 24, \$73-9; Ill. Laws 1953, p. 43r (H.B. 609).

${ }^{60} 68$ Stat. 610, I2 U.S.C.A. \$r73Ib(i) (1954 Supp.). See also Massachusctts statute referred to in note 58 , supra.

${ }^{\text {ar }}$ Penataquit Ass'n v. Furman, Sup. Ct. Suffolk Co., N.Y.L.J. Nov. 10, 1953, p. 1407, col. x.

${ }^{88}$ Reem v. Daves, 3 I Idaho 730, 175 Pac. 959 (I9I8) (mandamus to compel city to order demoli-
} 
In some cities, depending on the wording of the local charter or statute, the private citizen may bring an information against the violator (where violation is a misdemeanor) in the name of the city, alleging violation of law. ${ }^{69}$ Further restrictions may be imposed by court rules that if a complaint is made by a private citizen, he must swear to the truth of his complaint and cannot allege a violation on information and belief. complaints, it seriously limits the use of this remedy in connection with most planning legislation, particularly housing and building codes.

\section{Conclusion}

Private enforcement is an oft-overlooked vehicle for harassed residents witnessing the decline of their neighborhood through the indifference and inability of city officials towards enforcement of the planning laws; it is also an oft-overlooked remedy for the harassed city official who does not have the staff to engage in systematic and regular enforcement through the usual penalty procedure. Under laws as described above the city official may, by cooperative arrangements with insurance companies and mortgagees, obtain their aid in enforcing some types of planning laws. Private enforcement could be strengthened if statutory changes clearly made violations a matter of title and a basis for ineligibility of mortgage investment by institutional lenders.

Perhaps one reason for not making greater use of these private means of enforcement is a hostility against private citizens turning "policeman." It is submitted that planning is a peculiarly bad area for this attitude to dominate. The attitude reflects a public belief that these measures are "police" measures designed to preserve the peace of the community. Since a major objective in all planning legislation is to regularize land use in order to preserve certain values economic and otherwise in the area affected, planning is a peculiarly appropriate place for community satisfactions in property ownership to express themselves. If the residents and property owners of any area are not concerned about the protection of their own neighborhood, there are few reasons which can be advanced as to why the city official should be interested. ${ }^{71}$

tion of building built in violation of ordinance); Garrou v. Teaneck Tryon Co., I I N.J. 294, 94 A.2d 332, 35 A.L.R.2d 1125 (1953) and Annotation.

${ }^{00}$ McQuillin, op. cit. supra note 59,\$27.08. The Illinois Cities and Villages Act (ILl. Rev. Stat. c. $24, \$ 10-8$ (I95I)) provides: "A warrant for the arrest of an accused person may issue upon the affidavit of any person that an ordinance has been violated; and that the person making the complaint has reasonable grounds to believe that the party charged is guilty thereof." In City of Spokane v. Robison, 6 Wash. 547, 33 Pac. 960 (1893) an information was filed by a private citizen complaining of a violation of the slaughterhouse ordinance. This method of beginning was upheld even though the City Charter provided that the City Attorney should conduct all prosecution. Contra: City of New Rochelle v. Beckwith, 268 N.Y. 315, I97 N.E. 295, 100 A.L.R. 991 (r935) (zoning ordinance). But cf. Marcus v. Village of Mamaroneck, 283 N.Y. 325,28 N.E.2d 856 (1940).

${ }^{70} \mathrm{See}$, e.g., Municipal Court Act of Chicago $\$ 27$ (ILl. Rev. STat. c. 37, \$382). The Corporation Counsel of Chicago has ruled the section referred to in note 69 is controlling of this section. 21 Ors. Corp. Counsel of Chicago 384 (1944).

${ }^{7}$ But of. International Citx Managers' Ass'in, Local Planning Administratton 247 (2d ed. 1948). 
Moreover, as Professor Ratcliffe pointed out in the article referred to at the beginning of this paper, ${ }^{72}$ if city planning is to affect city growth and development, it must be because controls are imposed on market forces or its institutions subjected to pressure. What better way to affect the market than to make use of factors already affecting the free market-the lending and title examining institutions, and the attitudes of buyers and sellers and users of land?

${ }^{72}$ See note $\mathrm{r}$, supra. 